Mariusz ŁUKASIK

Poznań

\title{
Socjotechnika antykonsumpcji w warunkach globalizacji
}

Z pozoru mogłoby się wydawać, że mówienie w warunkach globalizacji o zjawisku antykonsumpcji w wymiarze socjotechnicznym jest co najmniej niedorzeczne. Ale tylko z pozoru, ponieważ już po chwilowym zastanowieniu sprawa wygląda zupełnie inaczej. Warto odrzucić wszelkie uprzedzenia i przyjrzeć się temu zjawisku, które przecież nie ogranicza się tylko do grup antysystemowych, pragnących w ten sposób zamanifestować swoją postawę, ale jest zjawiskiem szerszym, obejmującym swym zasięgiem większość społeczeństwa i przez to mającym charakter wyraźnie socjotechniczny. W takiej też perspektywie będzie rozpatrywane. Celem prezentowanego szkicu jest określenie istoty socjotechniki antykonsumpcji oraz wskazanie potrzeby, na którą obecnie ona odpowiada. Zarysowany zostanie także główny mechanizm, na którym oparta jest socjotechnika antykonsumpcji oraz środki, jakimi posługują się podmioty sterujące w celu osiagnięcia zamierzonych celów.

Przez socjotechnikę należy rozumieć proces rozszerzonej reprodukcji porządku społecznego. Według P. Pawełczyka proces ten ukierunkowany jest na zmianę stosunków społecznych, zakorzenienie w świadomości ludzkiej nowych wartości, w którym bardzo trudno dają się określić konkretne podmioty oddziaływania, przenika on bowiem cały organizm społeczny, a funkcjonalnymi wobec niego mogą być elementy nawet najniższych szczebli zinstytucjonalizowania społecznego ${ }^{1}$. Wskazuje, że proces socjotechniczny odbywa się mimowolnie, a podmioty, które wydają nam się podmiotami wpływającymi na społeczeństwo po prostu wykorzystuja tylko relacje zachodzące w środowisku społecznym, podtrzymując lub tworząc nowe instytucje z nimi związane, czy też wykorzystując wiedzę o łańcuchach przyczynowo-skutkowych zjawisk społecznych i operują odpowiednio bodźcami. Charakterystyczne dla tego procesu jest to, że

1 P. Pawełczyk, Socjotechniczne aspekty gry politycznej, Poznań 2000, s. 98. 
mamy do czynienia ze świadomością jego zachodzenia, możemy dostrzec jego efekty, lecz opisanie przebiegu i inspiratorów tego procesu jest znacznie trudniejsze. Socjotechnika jest odpowiedzialna za przekazywanie wartości długotrwałych wiążących się z ideowymi założeniami systemu społecznego (np. w modelowym ujęciu liberalnej demokracji wolność i równość) oraz wartości specyficznych dla systemu funkcjonującego w określonym przedziale czasowym (wyznaczanych np. przez ważne wydarzenia polityczne i społeczne $)^{2}$. Cel socjotechniki antykonsumpcji związany jest ze stabilnym funkcjonowaniem demokratycznego systemu politycznego w warunkach globalizacji. Socjotechnika antykonsumpcji (charakter negatywny) jest przeciwieństwem socjotechniki konsumpcji (charakter pozytywny).

\section{Socjotechnika konsumpcji}

W ogólnym rozumieniu konsumpcję traktuje się jako wszelkie zaspokajanie potrzeb ludzkich ${ }^{3}$. Takie ujęcie nie może satysfakcjonować przedstawiciela nauk społecznych. M. Golka dokonał pewnego podsumowywania atrybutów tego zjawiska, według niego konsumpcja ${ }^{4}$ :

- jest procesem nabywanie dóbr, które nie są niezbędne do przeżycia;

- w swej żarłoczności dąży do ogarnięcia wszystkich możliwych dóbr i wszystkich ludzi, do wypełnienia wszelkich możliwych nisz, w tym potrzeb patologicznych;

- jest spektakularnym działaniem na pokaz i służy walce o prestiż, a ostatecznie o sukces ekonomiczny jednostki, o jej ,panowanie” czy choćby górowanie nad innymi, ewentualnie zdystansowanie się od nich;

- jest związana ze sztucznie wytwarzanymi potrzebami czy raczej pragnieniami, zachciankami, kaprysami;

- nie ma granic, zazwyczaj też więcej obiecuje niż może jednostce dać;

- jest związana z zazdrością i wywołuje zazdrość, może mieć też z tego powodu charakter neurotyczny;

- związana jest z mediami, które wmawiają obywatelom ich „potrzeby” aż do stanu, odczuwanego przez odbiorcę jako swoisty przymus, którego źródła są niewidzialne i nader dyskretne;

2 Ibidem, s. 79.

C. Bywalec, L. Rudnicki, Konsumpcja, Warszawa 2002, s. 13.

4 M. Golka, Wchodzenie w cywilizację konsumpcyjna, w: M. Golka (red.), Nowe style zachowań, Poznań 2001, s. 177-178. 
- współtworzy ogólnospołeczny system wartości, w którym zajmuje jedno z najważniejszych miejsc, a przy okazji jest jednym z najistotniejszych czynników wpływających na współczesne życie jednostkowe i społeczne;

- jest istotnym mechanizmem, a nawet warunkiem reprodukcji, trwania i rozwoju współczesnej gospodarki rynkowej (całego systemu współczesnej cywilizacji przemysłowej);

- staje się jednym z najistotniejszych zjawisk ponadnarodowych, globalnych, jest wręcz jednym z czynników globalizacji;

- jest współczesną wersją osiągania przez jednostkę szczęścia czy choćby jego złudzenia.

Z powyższego katalogu atrybutów zjawiska, jeden z punktu widzenia artykułu wydaje się najistotniejszy. Chodzi mianowicie, o charakter potrzeb, które zaspakajamy w procesie konsumpcji. Należy podkreślić, że konsumpcja to zaspokajanie pragnień oraz zachcianek, które nie są konieczne do przeżycia (potrzeby nieelementarne). Taki też pogląd przeważa w większości opracowań dotyczących tego problemu. O konsumpcji, nie można mówić w przypadku zaspokajania potrzeb człowieka koniecznych do przeżycia (potrzeby elementarne).

Z socjotechniką konsumpcji skierowaną do ogółu społeczeństwa mieliśmy do czynienia w państwach określanych jako welfare state. Funkcjonowanie ich możliwe było dzięki specyficznym warunkom istniejącym w tamtym okresie na świecie. Jak wskazuje Claus Offe: „Społeczny, ekonomiczny i polityczny porządek został zbudowany w końcu lat 40. i na początku 50. wokół szerokiego liberalno-demokratycznego consensusu - koncepcji państwa dobrobytu, która nie była podważana przez jakąkolwiek znaczącą siłę polityczną ani z prawa, ani z lewa. Ta ugoda ustrojowa nie tylko opierała się mocno na «posttotalitarnym consensusie», lecz była także sankcjonowana i wzmacniana przez międzynarodową konfigurację sił, jaka wyłoniła się po II wojnie światowej”"5. Porządek ten był swoistą synergią pomiędzy demokracją a kapitalizmem, w którym ograniczeniom podlegała zarówno demokracja, jak i sam kapitalizm (w granicach państwa narodowego były zmuszone do pewnych ustępstw). W wyniku demokratyzacji większości instytucji społecznych, welfare state charakteryzowało się względnie płaską strukturą dochodów, która umożliwiała szerokiej rzeszy społeczeństwa uczestnictwo w sukcesach wzrostu gospodarczego.

5 C. Offe, Nowe ruchy społeczne, w: J. Szczupaczyński (wyb. i opr.), Władza i społeczeństwo, Warszawa 1995, s. 227. 
„Ukryte socjologiczne założenie, leżące u podstaw ustrojowej organizacji państwa dobrobytu mówiło, iż wzory życia skoncentrowane wokół «prywatności», a więc rodziny, pracy i konsumpcji, absorbują energię i aspiracje większości obywateli. Wobec tego uczestnictwo w konflikcie wokół polityki państwa będzie przedmiotem marginalnego zainteresowania większości społeczeństwa" "6. Welfare state charakteryzowało ukierunkowanie sterowania społeczeństwem na „dążenie do”, które oparte było na mechanizmie potęgowania potrzeb nieelementarnych. Polega on na wzniecaniu potrzeb nieelementarnych oraz wskazywaniu i reglamentowaniu sposobów zaspokajania tych potrzeb ${ }^{7}$. System sterujący ${ }^{8}$ wytworzył i rozpowszechniał ideologię konsumpcji, czyli starał się o to, aby najbardziej istotne kryteria wartości w społeczeństwie były tymi, które potęgują potrzeby ekspansji. Wartości, postawy i zachowania związane z konsumpcją miały stać się najważniejszymi wyznacznikami i uwarunkowaniami życia codziennego każdej jednostki. Socjotechnika konsumpcji miała utwierdzić jednostkę w przeświadczeniu, że konsumpcja dóbr jest największym źródłem przyjemności, najwyższą miarą ludzkich osiagnięć. Czyniła z konsumpcji podstawę ludzkiego szczęścia. Ideologia konsumpcji była wytworem warunków welfare state, odpowiadała jej potrzebom, czyli zachowaniu stabilności systemowej. Stąd dość często społeczeństwa te określano konsumpcyjnymi.

Podsumowując ten wątek, socjotechnika konsumpcji charakterystyczna była dla welfare state. Co prawda dyskurs antykonsumpcyjny obecny był w tych państwach od początku ich istnienia, ale miał charakter marginesowy. Poprzez analizę w stylu marksowskim (analiza systemu miała stanowić zarazem jego krytykę), był wyrazem sprzeciwu wobec zasad funkcjonującego w tych państwach porządku społecznego. Autorami tego dyskursu byli zarówno myśliciele i naukowcy spoza głównego nurtu ideologicznego ${ }^{9}$, jak i literaci, artyści, aż do skrajnych grup antysystemowych, określanych terrorystycznymi (np. RAF).

6 Ibidem, s. 228.

7 J. Rudniański, Elementy prakseologicznej teorii walki, Warszawa 1983, s. 97.

8 Za Pawełczykiem przyjmuję, że nadawcą socjotechnicznej wizji w skali makro jest układ instytucji zabezpieczający reprodukowanie niezbędnych dla żywotności systemu wartości. P. Pawełczyk, op. cit., s. 151.

9 Społeczeństwo konsumpcyjne poddawali krytyce m.in. J. Baudrillard, La societe'de consommation, Paris 1990; G. Debord, Społeczeństwo spektaklu, Gdańsk 1998; H. Marcuse, Człowiek jednowymiarowy, Warszawa 1991; R. Vaneigem, Rewolucja życia codziennego, Gdańsk 2004. 


\section{Globalizacja - nowe warunki funkcjonowania systemu demokratycznego}

Cezura roku 1989 wyznacza początek nowych warunków na świecie (powszechnie określanych jako globalizacja), które są splotem wielu procesów, a które stworzyły nowe możliwości dla ekspansji kapitalizmu na obszary, nad którymi panowanie jest niezbędnym warunkiem jego dalszego rozwoju. Najtrafniej ujął to E. Luttwak, pisząc: „Nazywają to wolnym rynkiem, ale dla mnie jest to kapitalizm z turbodoładowaniem, w skrócie turbokapitalizm, ponieważ zupełnie różni się od ściśle kontrolowanego kapitalizmu, który tkwił od 1945 r. do lat 80. i który przyniósł sensacyjną nowość masowej zamożności ludzi w Europie Zachodniej, Japonii i wszystkich innych krajach, które poszły w ich ślady" "10. Obecny turbokapitalizm ma zawsze opcję wyboru miejsca swojej ekspansji, natomiast państwo takiej opcji jest pozbawione, co w konsekwencji determinuje jego działanie i jego instytucji. W tych nowych warunkach rzeczywisty kierunek socjotechniki w skali globalnej jest wyznaczany przez zasady gospodarki kapitalistycznej, a tylko formalny (deklarowany) przez zasady demokracji liberalnej. Taki kierunek wprowadza zasadnicze zmiany w warunkach, zarówno politycznych, jak i socjoekonomicznych, funkcjonowania państw. Warunki globalizacji (likwidacja welfare state - poprzez demontaż instytucji społecznych, mających dbać o małą rozpiętość płac w społeczeństwie) to całkiem nowy rozkład dochodów w społeczeństwie, a także odejście od bezpieczeństwa socjalnego (uciążliwego dla systemu sterującego $)^{11}$. Mamy do czynienia ze zjawiskiem „zwycięzca bierze wszystko”, które oznacza niewielką grupę społeczeństwa o ogromnych dochodach oraz pozostałą grupę o dochodach pozwalających właściwie tylko na egzystencję $^{12}$ (lub nawet nie pozwalających na egzystencję - czyli zaspokojenie potrzeb elementarnych) ${ }^{13}$. Do tej pory taki rozkład dochodów charaktery-

10 E. Luttwak, Turbokapitalizm, Wrocław 1999, s. 42.

11 Sytuację tę doskonale pokazuje Raport ONZ z 25 sierpnia 2005 roku, The Inequality Predicament", http:/www.un.org/esa/socdev/rwss/media\%2005/cd-docs/media.htm.

12 T. L. Friedman, Lexus i drzewo oliwne, Poznań 2001, s. 375.

13 Znana amerykańska pisarka i dziennikarka w ramach tzw. obserwacji uczestniczącej postanowiła zbadać, czy można utrzymać się za minimalną stawkę w kraju, w którym wciąż jeszcze króluje mit „od pucybuta do milionera”. W ramach trwającego dwa lata eksperymentu B. Ehrenreich była kelnerką w Key West na Florydzie, sprzątaczką w Portland oraz ekspedientką w największej amerykańskiej sieci sklepów Wal-Mart w Minesocie. Wnioski z jej eksperymentu są przygnębiające. Z pracy, którą 
styczny był tylko dla krajów Trzeciego Świata, globalizacja powoduje, że w coraz większym stopniu zjawisko to zaczyna występować w krajach zachodnich. Na zjawisko ogromnej rozpiętości płac w warunkach globalizacji zwrócili uwagę nawet badacze z liberalnego kręgu. R. Dahrendorf pisze, że jeśli nierówności mogą być źródłem nadziei i postępu w środowisku, które jest wystarczająco otwarte, aby umożliwić ludziom (dzięki ich własnemu wysiłkowi) poprawę szans życiowych, to nowa nierówność jest innego rodzaju. Określa on ją jako „unierównienie” - przeciwieństwo niwelowania, dla niektórych budowanie ścieżek na szczyt, a kopanie dołów dla innych, co tworzy rozłamy i dezintegruje społeczeństwo ${ }^{14}$. Dwaj francuscy badacze zwracają uwagę, że pod wpływem m.in. globalizacji ciężar nierówności w państwach Zachodu ujmuje się dziś w nowych kategoriach, które wynikają z nakładających się dwóch zjawisk: rozszerzają się nierówności strukturalne (tzw. tradycyjne), jednocześnie jednak rozszerzeniu ulega pole nierówności, co powoduje pojawienie się nierówności nowego rodzaju, które wynikają z uwzględnienia różnic wewnątrz grup traktowanych uprzednio jako jednorodne ${ }^{15}$. Nierówności te, które oni określają jako dynamiczne, zdają się tylko dobitniej potwierdzać zasadę „zwycięzca bierze wszystko”. Jakkolwiek szczegółowe proporcje płacowe często przedstawiane są różnie, to jednak ogólną tendencję związaną z bogaceniem się nielicznych, a ubożeniem większości, podzielają prawie wszyscy badacze, niezależnie od wyznawanych poglądów. Słusznie zauważa Pawełczyk, że w takich warunkach (czyli polaryzacji materialnego statusu różnych grup społecznych) trudno mówić o jednym ogólnym modelu konsumpcji ${ }^{16}$. Według niego model konsumpcji należy rozumieć jako odpowiadającą ukształtowanym przyzwyczajeniom i upodobaniom strukturę konsumpcji dóbr i usług, służących zaspokajaniu potrzeb społeczeństwa. Jest to uproszczony obraz faktycznych zachowań konsumpcyjnych, będących wynikiem działania szeregu czynników zarówno subiektywnych (wybór określonego wzorca indywidualnego), jak i obiek-

w Stanach wykonują całe rzesze ludzi, nie można przeżyć na minimalnym poziomie, a w dodatku pociaga ona za sobą wysokie koszty psychiczne, zdrowotne i społeczne. B. Ehrenreich, Za grosze. Pracować i (nie) przeżyć, Warszawa 2006.

14 R. Dahrendorf, Perspektywy rozwoju gospodarczego, spoleczeństwa obywatelskiego i wolność polityczna, w: J. Danecki, M. Danecka (red.), U podłoża globalnych zagrożeń. Dylematy rozwoju, Warszawa 2003, s. 39.

15 J.-P. Fitoussi, P. Rosanvallon, Czas nowych nierówności, Kraków 2000, s. 53.

16 P. Pawełczyk, Polityczny model konsumpcji, Toruń 1994, s. 7. 
tywnych (polityka cen, dochodów, wielkości produkcji itp.) W dalszej części za Pawełczykiem, aktualną strukturę potrzeb konsumpcyjnych odpowiadającą preferencjom i możliwościom ludności, określam mianem modelu konsumpcji, natomiast pożądaną strukturę jako wzorzec konsumpcji, który jest postulatem pod adresem społeczeństwa, kształtowanym za pomocą odpowiednich środków społecznych, politycznych i ekonomicznych. Model jest wynikiem praktycznej realizacji wzorca ${ }^{17}$. Jeśli w społeczeństwie dobrobytu można było mówić o jednym modelu konsumpcji, który był praktycznym wynikiem jednego wzorca (kształtowanego przez socjotechnikę konsumpcji), tak w warunkach globalizacji można mówić o co najmniej dwóch modelach konsumpcji, charakteryzujących dwie grupy społeczne (kryterium ich wyodrębnienia to dochód). Te dwa modele będą oczywiście praktyczną realizacją dwóch wzorców konsumpcji.

Należy także pamiętać, że wbrew temu co twierdzą niektórzy, kapitalizm nie musi być oparty na jednym modelu konsumpcji. Jak pisze L. C. Thurow: „Jeśli chodzi o dystrybucyjną stronę równania, kapitalizm może się również dobrze dostosować do całkowicie egalitarnego rozkładu siły nabywczej (wszyscy mają taki sam dochód), jak i do skrajnie nieegalitarnego rozkładu (jedna osoba posiada cały dochód narodowy poza tym, jaki jest konieczny do zapewnienia minimum utrzymania reszcie ludności). Kapitalizm wytwarzałby po prostu różny asortyment towarów, by zaspokoić różne gusta"18.

\section{Hiperkonsumpcja}

W warunkach globalizacji mamy do czynienia z nowym modelem konsumpcji - hiperkonsumpcją, charakteryzującym nieliczną grupę o najwyższych dochodach (często tę grupę określa się jako wygraną w procesie globalizacji $^{19}$. Model ten jest praktyczną realizacją wzorca, który kształtowa-

17 Ibidem, s. 19-20.

18 L. C. Thurow, Przyszłość kapitalizmu, Wrocław 1999, s. 318.

19 „Według tygodnika «Forbes» na świecie jest 793 miliarderów, a ich liczba z roku na rok rośnie o ok. 15 proc. To oni stanowią trzon konsumentów uber premium. Konsumentów naprawdę bogatych, których stać jest na rzeczy niewyobrażalne: luksusowe apartamenty na bajecznej wyspie w Zatoce Perskiej, wycieczki turystyczne w kosmos czy oryginalne kreacje Chanel sięgające 250000 euro za sztukę. Jak powiedział Tyler Brule: «uber premium jest tym co dzieli Nic-Nie-Posiadaczy od Wszyst- 
ny jest przez socjotechnikę konsumpcji. Tylko nieliczna grupa w obecnych warunkach spełnia dwa podstawowe warunki uczestnictwa w konsumpcji: odpowiednie zasoby finansowe oraz wolny czas. Przedmiotami sterowanymi w socjotechnice konsumpcji są także grupy, które posiadają tzw. zdolność kredytową i mogą cieszyć się konsumpcją z pomocą kredytów. Pod względem ilościowym i jakościowym obecna hiperkonsumpcja elit różni się zasadniczo od konsumpcji elit okresów poprzednich. W znacznie mniejszym stopniu jest to konsumpcja ostentacyjna, którą opisywał T. Veblen $^{20}$. G. Ritzer sądzi, że obecnie dużą część konsumpcji charakteryzuje ostentacyjny brak ostentacji. Pisze: „W przeszłości mogliśmy się starać odróżnić od innych, dziś być może bardziej nam zależy na demonstrowaniu wspólnoty z większością. Możliwe też, że ludzie nie chcą się za bardzo wyróżniać z tłumu. Że zdając sobie sprawę z wysokiej przestępczości, większość ludzi woli się nie odróżniać od innych, w każdym razie nie sposobem publicznej konsumpcji bądź wyglądem"21. Zauważa on, że nawet wśród współczesnej klasy próżniaczej, dominuje konsumpcja bez ostentacji. Powody są tutaj takie same jak w przypadku pozostałej części społeczeństwa. Jak pisze Castells: „Wzorzec konsumpcji ostentacyjnej zastępuje tu konsumpcja zbyteczna, czyli nabywanie dóbr, z których właściciel ma niewielki pożytek, ale które dają mu chwilową satysfakcję w czasie wolnym od pracy: rezydencje, różnego rodzaju pojazdy - im dziwaczniejsze, - tym lepiej - niezwykłe wakacje, ekstrawaganckie przyjęcia (aczkolwiek nieczęste, wyrafinowane zabiegi lecznicze i osobiści instruktorzy medytacji)"22. Do tego zbioru można także zaliczyć wszelkie kolekcje (od dzieł sztuki wartych miliony dolarów do całych kolekcji maskotek np. lalek Barbie). Kolekcjonerstwo przez niektórych uważane jest za najwyższe stadium konsumpcji. Konsumpcja zbyteczna bardziej odnosi się do przeżyć niż do rzeczy. Rację ma Z. Bauman powtarzając wielokrotnie, że konsumpcjonizm nie polega na kolekcjonowaniu i gromadzeniu dobytku, ale na gromadzeniu wrażeń (niekoniecznie przyjemnych, a przynajmniej niekoniecznie przyjemnych z natury $)^{23}$. Dlatego nie bez przyczyny, globalni

ko-Posiadaczy»”. M. Kapłan, Uber Premium czyli nowe spojrzenie na segment dóbr luksusowych, „Brief” 2007, nr 5.

20 T. Veblen, Teoria klasy próżniaczej, Warszawa 1971.

21 G. Ritzer, Magiczny świat konsumpcji, Warszawa 2001, s. 332.

22 M. Castells, Galaktyka Internetu, Poznań 2003, s. 72.

23 Z. Bauman, Społeczeństwo w stanie oblężenia, Warszawa 2006, s. 180. 
turyści zostali okrzyknięci nową klasą próżniaczą ${ }^{24}$. Ten nowy model konsumpcji oparty na wrażeniach strona trendwatching.com nazwała ,transumentami" - poszukiwaczami przyjemności, wydającymi pieniądze w sposób zupełnie inny od poprzednich pokoleń. Transumenci nie potrafią długo poświęcać uwagi jednej sprawie, łatwo się nudzą, wolą przeżywać niż posiadać i martwią się, że własność może być synonimem kłopotów i monotonii. Starają się żyć tak, jakby byli na nieustających wakacjach. Wyrzekają się formalności, uciekają przed zobowiązaniami i częściej wypożyczają niż kupują - czy to dom, samochód czy nowy strój ${ }^{25}$. Konsumpcja elit dotyczy także władzy. Thurow zauważa, że ,[...] po przekroczeniu pewnego poziomu materialnej zamożności celem posiadania dodatkowych pieniędzy nie jest już materialna konsumpcja (jest wielu ludzi, którzy w żaden sposób nie mogą do końca życia skonsumować swego obecnego bogactwa, a jednak poświęcają życie pomnażaniu swoich pieniędzy), lecz możliwość podejmowania decyzji - ekonomicznych lub politycznych. Władza jest najwyższym dobrem konsumpcyjnym. Niemalże jako jedyna jest pożądana - i może być używana - w nieograniczonych ilościach"26. Najskrajniejszym przykładem takiej sytuacji była przez jakiś czas włoska demokracja ${ }^{27}$. Wydaje się, że nie ma granic hiperkonsumpcji elit. Na podbój wciąż czekają inne planety, sprzedaż działek na księżycu stała się już faktem, powoli także rozwija się rynek turystyki kosmicznej. Zapewne obecna elita ekonomiczna nie może i nie będzie mogła narzekać na brak nowych możliwości konsumowania.

\section{Socjotechnika antykonsumpcji}

W warunkach globalizacji, kontynuowanie socjotechniki konsumpcji, czyli opartej na mechanizmie potęgowania potrzeb nieelementarnych w stosunku do całego społeczeństwa (bez możliwości ich realizacji przez

24 D. MacCannell, Turysta: nowa teoria klasy próżniaczej, Warszawa 2002. 25 http://trendwatching.com/trendreport/.

26 L. C. Thurow, op. cit., s. 329.

27 Na przełomie wieków XX/XXI we Włoszech premierem rządu był S. Berlusconi, magnat przemysłowy będący jednocześnie najbogatszym i najpotężniejszym człowiekiem w tym kraju (właściciel największych stacji TV, firm budowlanych, ubezpieczeniowych, wydawnictw książkowych i prasowych. Niektórzy komentatorzy sytuację, w której szef rządu traktuje naród jako swoją firmę, określali jako „Włochy SA”. T. Assheuer, „Die Zeit” z 04.04.2002, za: Ułomna demokracja, ,Forum” 2002, nr 25, s. 20. 
większość społeczeństwa), prowadziłoby do nadmiernej frustracji społeczeństwa, czyli, mówiąc językiem psychologów, powodowałoby nieprzyjemne napięcia, stany emocjonalne z tym związane, objawiające się wzrostem agresji wśródgrupowej lub międzygrupowej albo też apatią i rezygnacją. Wynikiem tego mogłaby być utrata stabilności systemu politycznego. P. Braud pisze: „System polityczny sam w sobie jest przyczyną frustracji, jako że każda władza coś nakazuje, czegoś zakazuje bądź pobudza nadzieje. Jednakże musi ona ukierunkować wszelkie objawy niezadowolenia (szczególnie typu ekonomicznego czy zawodowego), gdy zrodzone nawet poza sferą jego działania, znajdą się na scenie politycznej. Frustracje te, będące źródłem aktywnej lub biernej agresywności, słownej bądź fizycznej, stawiają rządy demokratyczne wobec podstawowego problemu regulowania przemocy społecznej" 28 . W świetle badań potwierdzających rolę czynników ekonomicznych w utrzymaniu stabilności systemu demokratycznego, nie można lekceważyć związków między systemem politycznym a dystrybucją dochodu i dóbr ${ }^{29}$. I chociaż - jak wskazuje F. Ryszka - inna jest natura potrzeb politycznych niż potrzeb ekonomicznych, to potrzeby ekonomiczne mają znaczenie przy „wejściu” do politycznego systemu i mogą ważyć silniej od potrzeb na wskroś politycznych, które w swoim aspekcie humanistycznym zdążają przede wszystkim do maksymalizowania wolności indywidualnej człowieka lub - wyrażając się w kategoriach analizy systemowej - do tego, aby system zapewniał człowiekowi maksimum swobód ${ }^{30}$. Dlatego też badacze podkreślają, że mając na uwadze konieczność utrzymywania i aktywizowania poparcia dla swojego funkcjonowania (decydującego o stabilności), żaden system polityczny nie może wyrzec się całkowitej możliwości oddziaływania w sferze kształtowania potrzeb konsumpcyjnych ${ }^{31}$. W warunkach realnego socjalizmu środki produkcji były we władaniu systemu politycznego

28 P. Braud, Rozkosze demokracji, Warszawa 1995, s. 11. Według Brauda stabilność demokracji będzie warunkowana utrzymaniem frustracji oraz agresywności społecznych na dopuszczalnym poziomie oraz wskazywaniem dróg wyjścia (autentycznych lub prawdopodobnych) odpowiadających oczekiwaniom rządzonych oraz ambicjom będących u władzy.

29 S. M. Lipset, Homo politicus, Spoleczne podstawy polityki, Warszawa 1998; A. Przeworski, M. Alvarez, J. A. Cheibub, F. Limongi, Democracy and Development: Political Institutions and Well-Being in the World, 1950-1990, Cambridge 2000.

30 F. Ryszka, op. cit., s. 378.

31 P. Pawełczyk, Polityczny model..., s. 21. 
i to on w zasadzie kształtował potrzeby społeczeństwa oraz odpowiadał za ich zaspokojenie. W welfare state, gdzie demokratyczny system polityczny współistniał wraz z kapitalistycznym systemem ekonomicznym, miał on przynajmniej częściowy udział w kształtowaniu i rzeczywistym zaspokajaniu potrzeb konsumpcyjnych społeczeństwa (dzięki pewnym instrumentom ekonomicznym). Inaczej sprawa wygląda w warunkach globalizacji, gdzie państwa muszą ex post dostarczać legitymizacji decyzjom, które często zapadają w sposób zupełnie niedemokratyczny, ograniczają politykę narodowa, a prawo działania przyznają gospodarce świtowej ${ }^{32}$. W sytuacji utraty możliwości wpływania na poziom zaspokajania potrzeb konsumpcyjnych społeczeństwa, system polityczny, co było wcześniej powiedziane nie może pozostać bierny w kwestii kształtowania tych potrzeb. Z powodu braku możliwości wytwarzania rzeczywistych wytworów, czyli dokonywania zmian w materialnym wymiarze rzeczywistości, system polityczny musi rekompensować sobie ten brak działaniami odnoszącymi się do zmian na poziomie werbalnego opisu tej rzeczywistości $^{33}$. Te pierwsze działania będą polityką konkretną, natomiast te drugie polityką symboliczną ${ }^{34}$.

Warunkiem stabilności systemu demokratycznego jest niedopuszczenie do pojawienia się frustracji, a w przypadku już ich wystapienia aktywne i skuteczne działanie, polegające na ukierunkowaniu ich w taki sposób, aby przyczyniły się do podtrzymania systemu, a nie jego załamania. Utrzymanie stabilności systemu w nowych warunkach wymusiło przemianę sposobu sterowania społeczeństwem. Wzorzec konsumpcji ukształtowany jeszcze w welfare state stał się wobec systemu dysfunkcjonalny, w sytu-

32 U. Beck, Władza i przeciwwładza w epoce globalnej. Nowa ekonomia polityki światowej, Warszawa 2005, s. 128.

33 Zmianę zachowań można osiagnąć nie tylko przez wprowadzenie zmian w materialnym wymiarze rzeczywistości społecznej, lecz również przez zmiany na poziomie jej werbalnego opisu. Takie działanie określamy mianem intencjonalnego kreowania obrazów rzeczywistości. M. Marody, Technologie intelektu, Warszawa 1997, s. 254.

34 „Ażeby prowadzić politykę, która zmierza do usatysfakcjonowania obywateli, możliwe są dwie strategie. Pierwsza usiłuje wpływać bezpośrednio na sytuacje praktyczne, z nadzieją przyczynienia się do regresji percepcji negatywnych oraz zmniejszenia wymagań. Druga próbuje wpływać na prezentacje - lub wierzenia, które je wywołują - w sposób pozwalający zmniejszyć maksymalne niezadowolenie. Prowadzi to do dwoistości: polityki konkretnej i polityki symbolicznej". P. Braud, op. cit., s. $237-238$. 
acji gdy zaspokojenie wielu potrzeb, poza tymi elementarnymi, w przypadku większości społeczeństwa stało się niemożliwe. Konieczne zatem stało się odejście, przynajmniej w stosunku do większości społeczeństwa, od socjotechniki konsumpcji na rzecz socjotechniki antykonsumpcji.

Celem oddziaływania socjotechniki antykonsumpcji jest kształtowanie wzorca konsumpcji, dostosowanego do możliwości większości społeczeństwa. Trzeba pamiętać, że napięcia powstałe na skutek niemożności realizacji potrzeb mogą być usunięte na dwa sposoby. Pierwszy to zrealizowanie oczekiwań społeczeństwa co do potrzeb konsumpcyjnych (takie rozwiązanie nie wchodzi obecnie w grę, kapitalizm nie po to wywalczył dla siebie bardziej dogodne warunki funkcjonowania, aby z powrotem cofać się do ograniczeń welfare state - w warunkach globalizacji ma pełną możliwość urzeczywistnić swą podstawową zasadę działania, czyli rozszerzoną reprodukcję kapitału), natomiast drugi to dostosowanie żądań społeczeństwa do możliwości ich wypełniania, czyli zmianę dotychczasowego wzorca konsumpcji. Właśnie zadaniem socjotechniki antykonsumpcji będzie likwidacja czynników powodujących wzrost frustracji społeczeństwa, a więc działanie przeciw nadmiernemu - z punktu widzenia systemu politycznego - rozwojowi potrzeb konsumpcyjnych. Strategicznym celem będzie zachowanie dobrej kondycji społeczeństwa ${ }^{35}$, w sytuacji gdy może ono sobie pozwolić, w związku z niskimi dochodami, tylko na zaspokojenie swych elementarnych potrzeb (jeśli można się po-

35 Dobra kondycja psychiczna społeczeństwa związana jest sytuacją optymalna, która ma miejsce kiedy subiektywne wyobrażenia społeczeństwa dotyczące oczekiwań pożądanego stanu realizacji potrzeb zarówno ekonomicznych, jak i politycznych, są kompatybilne z możliwościami systemu w kwestii ich realizacji oraz istniejące realnie nierówności są akceptowane i postrzegane są jako sprawiedliwe (stan akceptacji nierówności najczęściej uzyskiwany jest poprzez wytworzenie przekonania u osób znajdujących się w dolnej części dystrybucji dochodu, że ich sytuacja jest lepsza niż rzeczywiście tak jest, poczucie to wzmacniane jest przez ich ogólne mylne wyobrażenie o rozkładzie tych dochodów w społeczeństwie, a także o pozycji, jaką zajmują w tym rozkładzie). Kompatybilne jednak nie znaczy identyczne, ponieważ - jak wskazuje von Beyme - do cech stabilności systemu zalicza się także pewne napięcie między ideałem a rzeczywistością, jeśli tylko ideał nie jest ujęty zbyt nierealistycznie i utopijnie. K. von Beyme, Współczesne teorie polityczne, Warszawa 2005 s. 219. Wynika to z faktu, że człowiek działa najefektywniej wówczas, gdy poziom jego aspiracji nieco tylko przewyższa możliwości ich zaspokojenia (dotyczy to, rzecz jasna, przeciętnych, a nie najsilniejszych osobowościowo jednostek). T. Kocowski, Taktyka i strategia sterowania motywacja ludzkq w skali masowej, w: A. Podgórecki (red.), Socjotechnika. Style działania, Warszawa 1972, s. 432. 
kusić o nazwanie tego nowego wzorca zaspakajania potrzeb większości społeczeństwa można powiedzieć, że jest to wzorzec egzystencjalny ${ }^{36}$ ). Jednoznaczne określenie zbioru potrzeb elementarnych chyba nie jest możliwe (właściwie powszechnie się uznaje, że nie istnieje kompletny i uniwersalny, mający swą obiektywną podstawę katalog ludzkich potrzeb, a wszystkie ustalane w danych okresach czasowych mają subiektywny charakter, ustalane są każdorazowo przez system sterujący), pewne jest jednak, że zbiór ten zmieniał się na przestrzeni wieków, a obecny jest daleko większy niż ten sprzed już nie kilkudziesięciu lat wstecz, lecz kilku. Wynika to bardziej z postępu cywilizacyjnego, niż z ustępstw kapitalizmu na rzecz społeczeństwa. Jeśli już rozszerzanie katalogu potrzeb elementarnych było wynikiem ustępstw ze strony kapitalizmu, to podyktowane było w głównej mierze funkcjonalnością jednostek w danej fazie jego funkcjonowania. Dlatego też na progu XXI wieku takie rzeczy jak komputer osobisty, telefon komórkowy zostały włączone to tego katalogu. Jak wskazują socjologowie dzisiejsza nowa klasa robotnicza to w głównej mierze ludzie pracujący za pomocą komputera, ale wykonujący mało skomplikowane zajęcia ${ }^{37}$. Odpierając zarzuty, mogące pojawić się w tym miejscu, należy wskazać, że wymiana tego sprzętu, czyli nabywanie nowego modelu nie jest wynikiem działań socjotechniki konsumpcji (ta grupa nie może sobie pozwolić na ciągłe zamiany podyktowane modą), lecz wynika z pewnej zmiany podyktowanej raczej użytecznością danego urządzenia, a nie modą. Przykładem jest choćby wymiana komputera osobistego. W tej grupie system sterujący niejako przyzwala na wymianę komputera na nowy (poprzez stworzenie takiej możliwości), tylko w przypadku, gdy stary przestaje spełniać funkcje przydatne do pracy, staje się

36 S. Townsend, autorka cyklu dzienników „Adrian Mole 13 i 3/4. Sekretny dziennik”, pisała o ,zerach z prowincji”, których „nie stać na styl życia, tylko na życie”. S. Łupak, Adrian Mole rzqdzi, ,Wysokie obcasy” z 12 maja 2007, nr 19 (420).

37 M. Hardt i A. Negri wskazują, że wśród różnych postaci produkcji, istniejących dzisiaj, coraz bardziej centralne miejsce - zarówno w systemie produkcji kapitalistycznej, jak w składzie proletariatu - zajmuje niematerialna siła robocza (zaangażowana w komunikacji, kooperacji oraz produkcji i reprodukcji uczuć. Piszą: ,pprzyrost wykorzystujących wiedzę miejsc pracy, polegających na twórczej manipulacji symbolami, powoduje odpowiedni przyrost miejsc pracy nisko ocenianych, niewymagających kwalifikacji, polegających na rutynowej manipulacji symbolami, takich jak wprowadzanie danych czy przetwarzanie tekstów. Tu wyłania się podstawowy podział pracy w obszarze produkcji niematerialnej”. M. Hardt, A. Negri, Imperium, Warszawa 2005, s. 312. 
dysfunkcjonalny wobec rozwoju technicznego systemu kapitalistycznego. Pojawiający się co róż nowy procesor, w początkowym okresie sprzedaży (czasem to jest nawet kilka lat) dostępny jest tylko dla nielicznych, głównie z powodu ceny.

Socjotechnika antykonsumpcji ma pokazać, że szczęście, dobre samopoczucie, zadowolenie nie jest związane tylko z konsumpcją. Jej celem jest kształtowanie postaw, które będą do konsumpcji odnosiły się negatywnie. Tak jak socjotechnika konsumpcji przygotowuje do pełnienia roli konsumenta, tak socjotechnika antykonsumpcji przygotowuje do roli świadomego antykonsumenta. Określenie „konsument” ma mieć mocno pejoratywne konotacje. Cała energia podmiotów sterowanych będzie kierowana na inne zajęcia. Zbiór będzie tutaj szeroki, zaczynając od działalności w charakterze wolontariatu, aż poprzez różnego rodzaju ideologie, zarówno religijne, jak i świeckie. Często zachowania takie mylnie określa się postkonsumpcjonizmem. Właściwe jest to co najwyżej do omawianych powyżej elit, które z własnej woli zrezygnowały z konsumpcjonizmu. Ileż razy słyszeliśmy $\mathrm{w}$ wywiadzie $\mathrm{z}$ osobą, o której wysokim poziomie zamożności jesteśmy przekonani, że jej model konsumpcji ogranicza się do potrzeb elementarnych, a podyktowane to jest jaką́s ideologią ${ }^{38}$. Członkowie elit moga zrezygnować z konsumpcji, ale zawsze będzie to ich własna i dobrowolna decyzja. Na skutek znużenia, lub z innych pobudek, mogą zacząć prowadzić życie nie uczestnicząc w procesie konsumpcji. Taką grupą było tzw. Pokolenie X opisane przez D. Couplanda w książce pt. Generation X: Tales of an Accelerated Culture ${ }^{39}$. W ten sposób, chyba w większości przypadków nieświadomie, stają się wzorami wykorzystywanymi przez podmioty sterujące w socjotechnice antykonsumpcji skierowanej już do większości społeczeństwa. Większość jednak pozbawiona jest takiego wyboru, to za sprawą turbokapitalizmu muszą zrezygnować z konsumpcji. „To, co dla jednych jest wolnym wyborem, na innych spada na mocy bezlitosnych wyroków losu" - pisze Bauman ${ }^{40}$.

38 Przykładem jest chociażby jeden z najbogatszych ludzi na świecie, twórca i szef globalnej korporacji IKEA I. Kamprad. W rozmowie z polskim dziennikarzem czaruje nas swoją skromnością, stara się utwierdzić czytelnika w przekonaniu, że jego konsumowanie ogranicza się tylko do rzeczy niezbędnych do życia. Pan IKEA, Rozmowa z Ingvarem Kampradem, w: J. Żakowski, Rozmowy o lepszym świecie, myśleniu $i$ zyciu, Warszawa 2005, s. 159-172.

39 D. Coupland, Pokolenie X: opowieści na czasy przyśpieszajacej kultury, Warszawa 1998.

40 Z. Bauman, Globalizacja. I co z tego dla ludzi wynika, Warszawa 2000, s. 84. 
Działania związane z socjotechniką antykonsumpcji pozwalają takiej jednostce racjonalizować swoją postawę. Dyskurs antykonsumpcyjny ma stanowić gotowe derywacje. Jednostka musi z odwagą prezentować swoje stanowisko i czuć się z tym dobrze.

Obecnie trudno tak naprawdę znaleźć instytucję, która by nie realizowała, oczywiście każda na swój sposób, działań polegających na propagowaniu antykonsumpcji. Jeśli chodzi o takie instytucje społeczne jak rodzina i szkoła to nie ma tutaj wątpliwości czym kierują się one w działaniu, są to instytucje odpowiedzialne za kształtowanie młodego pokolenia zgodnie z panującymi wartościami. Można by rzec, że są to instytucje systemowe, świadomie podejmujące takie kroki. Rodzice, właściwie w każdym społeczeństwie, na zasadzie pewnego automatyzmu, chcąc uniknąć tzw. kłopotów wychowawczych, dostosowują żądania (także w aspekcie potrzeb materialnych) swoich dzieci do realnych możliwości ich zaspokojenia (już Fromm pisał, że rodzina jest agentem społeczeństwa). W związku z faktem, że realne możliwości większości rodzin w tym względzie są niewielkie, dlatego też w tych rodzinach dominuje dyskurs antykonsumpcyjny ${ }^{41}$. Wskazuje się, że jednym z zadań szkoły jest wychowanie tzw. „Świadomego konsumenta" (Świadomy konsument to konsument, który potrafi prawidłowo zrozumieć kierowane do niego informacje. To konsument krytyczny, chętnie zdobywający nowe doświadczenia i wiedzę, korzystający z możliwości stwarzanych mu przez akcje informacyjne i edukacyjne do niego adresowane, a nie „niedbały” i „,iemny”. Świadomy konsument nie wierzy we wszystko, co podają reklamy, czyta uważnie etykiety, porównuje oferty w różnych sklepach, bankach i zakładach usługowych zanim podejmie decyzję). Jest to pewien eufemizm, mający przysłonić rzeczywisty cel wychowania, którym jest postawa, jeśli już nie wroga konsumpcjonizmowi, to przynajmniej traktująca go z dystansem. Do uczniów szkół, właściwie na wszystkich poziomach, skierowanych jest wiele akcji, tak naprawdę zniechęcających do konsumpcji ${ }^{42}$. Może w mniejszym stopniu, ale także w pewnym względzie instytucją syste-

41 Na rynku nie brak pomocy w tym zadaniu. Istnieje m.in. bogata literatura w tym względzie: A. Braun, Czy dzieci muszq mieć wszystko, Kielce 2004.

42 Obecnie realizowana jest ogólnopolska kampania edukacyjna „Co młody konsument wiedzieć powinien?” finansowana ze środków Unii Europejskiej oraz Urzędu Ochrony Konkurencji i Konsumentów. Celem kampanii jest rozbudzenie świadomości konsumenckiej wśród dzieci i młodzieży oraz dostarczenie młodym konsumentom informacji o ich najważniejszych prawach i obowiązkach. 
mową jest obecnie kościół, nie tylko katolicki, choć ten ze względu na liczbę swych wiernych w krajach demokratycznych odgrywa największą rolę. Trudno byłoby wymienić tutaj wszystkie dokumenty kościoła sygnowane rękami papieży, wpisujące się w dyskurs antykonsumpcjonizmu. Zjawisku nadmiernej konsumpcji najmocniej sprzeciwiał się nasz rodak Jan Paweł II ${ }^{43}$. Mamy także instytucje, które chyba w sposób nieświado-

43 „Wypada teraz zwrócić uwagę na specyficzne problemy i zagrożenia, które powstają w najbardziej rozwiniętych strukturach gospodarczych i wiążą się z ich charakterystycznymi cechami. W poprzednich fazach rozwoju człowiek żył zawsze w obliczu konieczności: jego potrzeby były nieliczne, narzucone poniekąd przez obiektywne struktury jego cielesnej natury, działalność zaś gospodarcza była nastawiona na ich zaspokojenie. Jest jednak oczywiste, że dziś problem polega nie tylko na tym, by dostarczyć człowiekowi odpowiednią ilość dóbr, ale także by zaspokoić zapotrzebowanie na jakość: jakość towarów produkowanych i konsumowanych, jakość usług, z których się korzysta, jakość środowiska naturalnego i życia w ogóle. Dążenie do coraz lepszych i bardziej zadowalających warunków życia i coraz większej zamożności jest samo w sobie uzasadnione; trudno jednak nie podkreślić związanych z tym etapem rozwoju nowych obowiązków i niebezpieczeństw. W sposobie powstawania i określania nowych potrzeb zawsze się wyraża mniej lub bardziej słuszna koncepcja człowieka i jego prawdziwego dobra. Poprzez decyzje dotyczące produkcji i konsumpcji ujawnia się określona kultura jako ogólna koncepcja życia. To właśnie tutaj powstaje zjawisko konsumizmu. Określając nowe potrzeby i nowe sposoby ich zaspokajania, koniecznie należy się kierować integralną wizją człowieka, która ogarnia wszystkie wymiary jego istnienia i która wymiary materialne i instynktowne podporządkowuje wewnętrznym i duchowym. Natomiast odwoływanie się bezpośrednio do jego instynktów i ignorowanie na różne sposoby jego wolnej i świadomej natury osobowej może prowadzić do wytworzenia nawyków konsumpcyjnych i stylów życia obiektywnie niegodziwych lub szkodliwych dla fizycznego i duchowego zdrowia. W samym systemie gospodarczym nie ma kryteriów pozwalających na poprawne odróżnienie nowych i doskonalszych form zaspokajania ludzkich potrzeb od potrzeb sztucznie stwarzanych, przeszkadzających kształtowaniu się dojrzałej osobowości. Dlatego pilnie potrzebna jest tu wielka praca na polu wychowania i kultury, obejmująca przygotowanie konsumentów do odpowiedzialnego korzystania z prawa wyboru, kształtowanie głębokiego poczucia odpowiedzialności u producentów i przede wszystkim u specjalistów w dziedzinie społecznego przekazu; konieczna jest także interwencja władz publicznych. Jaskrawym przykładem konsumpcji sztucznej, szkodliwej dla zdrowia i godności człowieka, oraz wymykającej się spod kontroli, jest używanie narkotyków. Szerzenie się narkomanii jest wskaźnikiem poważnych zaburzeń w funkcjonowaniu systemu społecznego i skłania do materialistycznej, poniekąd destruktywnej, interpretacji ludzkich potrzeb. Dochodzi do tego, że twórcze możliwości wolnej gospodarki urzeczywistniają się w sposób jednostronny i niewłaściwy. Narkotyki, a także pornografia i inne formy konsumizmu, wykorzystując nieodporność jednostek słabych, mają wypełnić duchową pustkę, jaka powstaje w człowieku. Pragnienie, by żyć lepiej, nie jest niczym 
my stały się podmiotami sterującymi w socjotechnice antykonsumpcji. Kontynuują one ślepo dyskurs antykonsupcyjny, zapoczątkowany jeszcze $\mathrm{w}$ welfare state przez przeciwników zasad tamtego porządku społecznego. Wpadli oni w pułapkę, ponieważ w tych nowych warunkach stają się jeśli nie rzecznikami obecnego porządku, to przyczyniają się aktywnie do jego stabilnego trwania. Myślę tutaj o dużej grupie artystów, literatów, naukowców. Propagowany przez nich dyskurs antykonsumpcyjny wpisuje się w socjotechnikę antykonsumpcji. Naukowy dyskurs antykonsumpcyjny, mający swoją genezę w świecie zachodnim, kontynuowany jest na polu licznych dyscyplin naukowych. Każda z nich, z właściwym sobie instrumentarium pojęć oraz podbudową ideologiczną, aktywnie przyczynia się do działań podmiotu sterującego. Praktycznego wymiaru dyskurs naukowy nabiera u psychologów, których rady szeroko wypowiadane, a następnie publikowane, są wskazówką dla społeczeństwa: „Trzeba tłumaczyć społeczeństwu, że lepszego samopoczucia nie zapewnią im pieniądze, większe mieszkania czy lepsze samochody, lecz zupełnie inne wartości”. Wydaje się, że powstanie i rozwój tzw. psychologii pozytywnej, która ma nas nauczyć żyć szczęśliwie (jedną z podstawowych rad serwowaną przez twórców tej psychologii jest taka, że pieniądze szczęścia nie dają), wpisuje się w socjotechnikę antykonsumpcji ${ }^{44}$. Jednakże naukowcom można

złym, ale błędem jest styl życia, który wyżej stawia dążenie do tego, by mieć, aniżeli być, i chce więcej mieć nie po to, aby bardziej być, lecz by doznać w życiu jak najwięcej przyjemności. Dlatego trzeba tworzyć takie style życia, w których szukanie prawdy, piękna i dobra, oraz wspólnota ludzi dążących do wspólnego rozwoju byłyby elementami decydującymi o wyborze jakości konsumpcji, oszczędności i inwestycji. W tym kontekście nie mogę ograniczyć się tylko do przypomnienia obowiązku miłosierdzia, czyli obowiązku wspomagania z tego, co „zbywa”, a czasem nawet $\mathrm{z}$ tego, co „potrzebne”, by dać ubogiemu to, co dla niego jest niezbędne. Mam na myśli fakt, że również decyzja o takiej, a nie innej inwestycji, w danej dziedzinie produkcji, a nie w innej, jest zawsze wyborem moralnym i kulturowym. Przy zaistnieniu pewnych warunków ekonomicznych i stabilności politycznej, absolutnie niezbędnych, decyzja o zainwestowaniu, czyli o daniu jakiejś społeczności okazji do dowartościowania jej pracy, płynie również z postawy ludzkiej sympatii i zaufania do Opatrzności, w czym ujawniają się ludzkie przymioty tego, kto decyduje”. Fragment encykliki „Centesimus Annus", Jan Paweł II, Rzym 1991.

44 Psychologia skupiała się do tej pory przede wszystkim na patologiach, na emocjach negatywnych. Na doprowadzeniu ludzi ze stanu „minus trzy” do stanu „zero” - jak thumaczy M. Seligmann, autor sztandarowego dzieła z zakresu psychologii pozytywnej pt. Prawdziwe szczęście. Jego zdaniem nadszedł w końcu czas stworzenia nauki, która stara się zrozumieć emocje pozytywne, kształtować zalety i cnoty oraz dostarczać wskazówek umożliwiających osiagnięcie tego, co Arystoteles nazwał „do- 
wybaczyć takie postępowanie. Przy obecnym uzależnieniu uniwersytetów, nie tylko od organów państwa, ale także instytucji ekonomicznych, coraz trudniej badaczom o krytycyzm wobec panującego porządku społecznego. Większe wymagania należy mieć co do osób, które przecież powołane są, jakby powiedział T. W. Adorno do ,zarażania chaosem porządku społecznego", które niejako z zasady powinny wykazywać się dużą dozą krytycyzmu wobec ideologii mającej podtrzymywać obecny porządek społeczny. Chodzi mi głównie tutaj o artystów, pisarzy, intelektualistów. To oni swoimi działaniami mają podważać zasadność głównego dyskursu ideologicznego, pokazywać na jakie potrzeby on odpowiada. Nie powinny brać jakiegokolwiek udziału w jego uprawomocnieniu. Jednak obecnie dzieje się inaczej. Większość (nie można tutaj generalizować, część środowisk literackich i artystycznych zachowało trzeźwość umysłu i nie bierze udziału na oślep w tego typu działaniach) artystów, czy to pisarzy swoimi działaniami skierowanymi przeciw konsumpcjonizmowi stała

brym życiem". Badacze z tego kręgu skonstruowali specyficzną drabinę szczęścia. Generalnie, według nich nie ma szczęścia bez innych ludzi (bez przyjaciół, bez rodziny i bez zaangażowania w tkankę społeczna). Na samym dole umieścili przyjemności. Chodzi tu o wszystko, co ulotnie zaspokaja nasze potrzeby fizyczne i estetyczne. Nie chodzi o to, by z nich rezygnować na drodze do szczęścia. Przeciwnie - warto nauczyć się je „zamrażać” we wspomnieniach. Tworzyć mentalne „fotografie” takich chwil. Ale właśnie marność, ulotność przyjemności przemawia za tym, by nie na nich budować szczęście. Seligmann tworzy pojęcie gratyfikacji - przyjemności wyższego rzędu, która wynika z przełamywania oporu, wysiłku, pracy. A gratyfikacja wymaga oddania się szlachetnemu celowi. Wspinaczka górska, postawienie sobie trudnego zadania i wykonanie go, niesienie pomocy, udział w pielgrzymce, oddanie się pasji tworzenia, poddanie się ,przepływowi”, czyli stanowi, kiedy człowiek jest czymś całkowicie pochłonięty, traci poczucie czasu i przestrzeni - to są normalnie słuszne przyjemności. $\mathrm{Na}$ drugim szczeblu drabiny psychologia pozytywna umieszcza właśnie więzi z ludźmi. Altruizm, a przede wszystkim okazywanie wdzięczności i wybaczanie. Jednak dobre relacje z ludźmi muszą być zrównoważone dobrymi relacjami z samym sobą. Pomaga to osiagnąć, jeden z długich testów, z którego można się dowiedzieć o swoich „zaletach sygnaturowych. Kluczowe dla poczucia harmonii i spełnienia zdaniem Seligmana jest dopasowanie swojego życia do własnych predyspozycji. Szczytem drabiny szczęśliwego życia wedle psychologów spod znaku Seligmana jest poświęcenie się wyższym celom. I tu niektóre postulaty tej szkoły wkraczają na pole religii, psychologicznej religii etycznej pozbawionej Boga. Zamiast Boga nowa nauka o szczęściu proponuje ideę dobra przyrastającego we wszechświecie dzięki porzuceniu przez ludzi zasad gry o sumie zerowej, zaś zastąpieniu jej ogólną zasadą gry o sumie niezerowej (obydwie strony zyskują, co ma miejsce na przykład w tak ważnym dla nauki o szczęściu akcie wdzięczności i wybaczania). Omówienie za: M. A. Velez, Szczęściologia - uszczęśliw się sam, „Przekrój” z 14 lutego 2007, nr 7. 
się agentami obecnego porządku społecznego. Nie jest wielkim odkryciem fakt, że w społeczeństwie nowoczesnym, większą rolę w kształtowaniu postaw odgrywają obrazy niż słowa ${ }^{45}$. Nie inaczej jest z propagowaniem postaw antykonsumpcyjnych, w których większą rolę odgrywa dyskurs artystyczny oparty na obrazie niż literacki oparty na słowie. Antykonsumpcyjny dyskurs literacki dociera do niewielkiej liczby osób, dla której w zdecydowanej części jest tylko przewodnikiem po konsumpcyjnym stylu życia. Jeśli już jakaś książka przedrze się do szerokiej publiczności, to nie poprzez fakt jej wysokiej jakości, a raczej reklamy, jaką jest otoczona ze strony wydawcy. Czasem dzieje się tak poprzez przyznanie jej licznych nagród. Takim głośnym przykładem jest książka proroka antykonsumpcjonizmu (sam się tak określa) S. Shutego pt. Zwał, która została nagrodzona Paszportem Polityki, przez co zarówno autor, jak i sama książka stały się znane szerokiej publiczności. Przyznanie nagrody autorowi tej książki (a po części całej ideologii - książka została wydana przez korporację Ha!art., której jeden z założycieli J. Sowa wylansował nawet na potrzeby nurtu pisarzy kontestujących kapitalistyczną rzeczywistość określenie „dezerterzy społeczeństwa konsumpcji”) przez „,szanowany” tygodnik opinii uwiarygodniło tylko całą ideologię antykonsumpcjonizmu. Jednostka otrzymała jasny sygnał, konsumowanie jest passe. Doczekaliśmy się także (o zgrozo), poetów i poezji antykonsumpcyjnej, która hołubiona jest przez krytyków.

Siłą obrazów atakują liczne akcje artystyczne, performance, filmy, wystawy piętnujące konsumpcyjny styl życia. Idąc śladem akcji typu „Dzień bez samochodu”, „Dzień bez papierosa”, organizuje się nawet „Dzień bez zakupów”. Używa się zmyślnych haseł typu „Tylko świnie siedzą w supermarkecie", będących parafrazą haseł jeszcze z czasów okupacji. Nie sposób tutaj przywołać przynajmniej części z tych akcji, które przeciwstawiały się zjawisku konsumpcji ${ }^{46}$. W zasadzie artyści sąjedną z najbardziej aktywnych grup szerzących antykonsumpcjonizm. Repertuar filmowy,

45 Już G. Le Bon pisał, że tłum umie myśleć wyłącznie obrazami i jest bardzo wrażliwy na obrazowe przedstawienie danego faktu lub rzeczy, tylko za pomocą takiego przedstawienia można tłum porwać i pobudzić go do działania. G. Le Bon, Psychologia thumu, Warszawa 1986, s. 84.

46 M.in.: „Okno 2005: multimedia i antykonsumpcjonizm”- jedne z największych w Polsce międzynarodowych spotkań twórców młodej sceny teatralnej, performerskiej, muzycznej i tanecznej. Czterodniowy festiwal prezentował sztukę współczesną, niepokorna. Tematami edycji 2005 były multimedia i antykonsumpcjonizm. 
który w zasadzie oparty jest na antykonsumpcjonizmie jest ogromny, by wymienić tylko takie filmy jak „Edukatorzy” reż. H. Weingartner czy „Idioci” reż. Lars von Trier, czy bardziej znane: „Fight Club” czy „American Beauty". Przeciw konsumpcji wypowiada się także teatr ${ }^{47}$. Twórcy graffiti także głosują przeciw konsumpcji ${ }^{48}$. Tak jak w przypadku literatów, także artyści szerzący tę ideologię znajdują uznanie instytucji, mediów głównego nurtu. Ostatnim takim przykładem jest nagrodzenie, także Paszportem Polityki grupy artystycznej „Twożywo”, której wkład w propagowanie antykonsumpcjonizmu jest znaczący (skądinąd niektóre akcje tej grupy trafnie punktują współczesny porządek społeczny, choćby grafika zwracająca uwagę na liczbę samobójstw w Polsce z hasłem: „Masobójstwo - 5500”). Nieco inny, ale także w przeważającej części antykonsumpcyjny charakter, mają zdjęcia corocznego konkursu World Press Foto.

Antykonsumpcjonizm oparty jest na różnorodnej argumentacji, która ma pokazać, że taka postawa jest w interesie całego społeczeństwa. Podstawowa zasada elementarza socjotechniki mówi, że zbieżność celu syste$\mathrm{mu}$ sterującego $\mathrm{z}$ celami systemu sterowanego gwarantuje najwyższą skuteczność sterowania. Lewicowi intelektualiści tradycyjnie już odwołują się do klasycznej krytyki kapitalizmu, która początek swój bierze u Marksa. Dla nich dążenie do maksymalizacji zaspokajania potrzeb jest przejawem wyzysku kapitalistycznego, dlatego każdy kto konsumuje ułatwia na dobrą sprawę życie kapitalizmowi. Jednakże nie biorą oni pod uwagę w swej krytyce nowych okoliczności, idąc na łatwiznę wpadają lekkomyślnie w pułapkę zastawioną przez obecną formę kapitalizmu. Dotyczy to także kontestatorów obecnego porządku w postaci antyglobalistów i alterglobalstów (w przeciwieństwie do antyglobalistów, którzy są krytykami tego procesu i jednocześnie nie widzą szansy w jego reformowaniu, alterglobaliści dostrzegają i wierzą w taką możliwość. Alterglobalizam to mówiąc ogólnie alternatywna forma globalizacji wobec obecnej,

47 Projekt teatralny pod hasłem „Po co tyle żreć - Szekspir”.

48 Jedną z najbardziej znanych polskich grup grafficiarzy jest 3Fala. Nazwa inicjatywy podkreśla przełomowy charakter prac. Po drugiej fali ulicznej twórczości - bardzo kolorowej, ale nie skłaniającej do myślenia - nadchodzi trzecia. Wraca do korzeni - lat osiemdziesiątych. Chce walczyć z władzą i konsumpcją. Grupa specjalizuje się w tak zwanym subvertisingu, czyli tworzeniu ,,antyreklam”. Wymownym przykładem jest tu chociażby domalowanie poniżej ogromnego loga Coca-Coli naturalnej wielkości ludzkiej postaci z obrazu ,Krzyk” Edwarda Muncha [http://doza.o2.pl/?s=4102\&t=6424]. 
która polegać ma na zrównoważeniu przewagi podmiotów ekonomicznych przez podmioty polityczne, czego strategią ma być globalna demokracja). Dla nich hasła „BORN TO BAY” mają niezwykle negatywny wydźwięk. Cieszy jednak fakt, że nie wszystkie lewicowe środowiska podejmują bezmyślnie ten dyskurs. Jedno z haseł pobocznych w kampanii wyborczej w 2005 roku do niemieckiego Bundestagu, nowej lewicowej partii „DIE Linke” brzmiało „Luxus fur Alle” (Luksus dla wszystkich). Dyskurs antykonsumpcyjny nie jest także obcy grupom sytuującym się po prawej stronie spektrum politycznego. Inne są tylko przesłanki, które nimi kieruja.

Jeszcze innego argumentu używają antykonsumpcyjnie nastawieni ekolodzy (chyba innych nie ma). Oni zaś argumentują, że zasoby surowcowe kończą się, a nadmierna konsumpcja prowadzi w prostej drodze do zagłady planety z powodu niekorzystnych zmian, jakie są efektem nadmiernej konsumpcji. Chcąc uratować naszą planetę musimy ograniczyć konsumpcję - takie jest stanowisko ekologów. Antykonsumpcjonizm znajduje także uzasadnienie na gruncie wielu ideologii, filozofii nie tylko życiowych, wyznań itp.

\section{Mechanizmy socjotechniki antykonsumpcji}

Socjotechnika antykonsumpcji w głównej mierze opiera się na różnych formach mechanizmu naśladownictwa (modelowania) ${ }^{49}$. Istota jego

49 Uczenie się na modelu było rozwinięciem koncepcji uczenia się instrumentalnego. Uczenie się na modelu zakłada, że nie tylko poprzez wzmocnienia, ale także, poprzez naśladowanie pewnego modelu możemy się uczyć pewnych zachowań. Uczenie się poprzez naśladowanie najpełniej w teorii rozwinął Albert Bandura poprzez wieloletnią pracę empiryczną i teoretyczną. Bandura spostrzegł, że oglądanie modelów nie tylko prowadzi do nabywania nowych zachowań, lecz także pociąga za sobą dwa inne rodzaje następstw. Po pierwsze, zachowanie modela może pobudzać do wykonania podobnych czynności, które znajdują się w repertuarze obserwatora. Wystąpienie takiego facylitującego wpływu jest szczególnie prawdopodobne wtedy, gdy dane zachowanie należy do społecznie aprobowanych. Drugi sposób oddziaływania modela na obserwatora występuje wtedy, gdy model wykonuje czynności zakazane społecznie lub odbiegające od normy. Obserwowanie modela może wzmocnić lub osłabić istniejące u obserwatora zachowanie dotyczące wykonywania tych czynności, zależnie od tego, czy zachowanie modela zostało ukarane, czy nagrodzone. Bandura rozwijając swoją koncepcję, zwrócił uwage jeszcze na inny rodzaj uczenia się opartego na obserwacji modela, a mianowicie zastępcze nabywanie uwarunkowanych reakcji emocjonal- 
działania różni się nieco od mechanizmu związanego z akceptacją społeczną, albowiem naśladowanie może zachodzić bez żadnych nagród i kar, a nawet przy dezakceptacji. „Mechanizm naśladownictwa skojarzony z oddziaływaniem na opinię w kierunku akceptacji pewnych norm prowadzi do socjotechniki osobowości wzorcowych, realizowanej przez środki masowego przekazu [...]. Jest to skuteczny środek oddziaływania, szczególnie na młodzież lub na grupy ludzkie charakteryzujące się zespołem cech noszących w psychologii miano niedojrzałości emocjonalnej (przewaga sterowania emocjonalnego nad racjonalnym) ${ }^{\text {"50 }}$. Naśladujemy nie tylko konkretne zachowania, lecz pewien styl życia, całe scenariusze relacji interpersonalnych.

$\mathrm{Z}$ mechanizmem naśladownictwa związane jest oddziaływanie za pomocą autorytetu. Osoby obdarzone autorytetem, czyli cieszące się prestiżem lub popularnością są w stanie oddziaływać swoim przykładem, poglądami na innych. Jak pisze Kocowski, autorytet nie musi się opierać na rzeczywistych walorach, może być on wyprodukowany sztucznie, mocą zewnętrznego splendoru, odpowiedniej propagandy lub przypisywanemu jednemu człowiekowi wszelkich możliwych zasług. Produkcja autorytetów to niemal rzecz charakterystyczna dla epoki mediów. Mamy z nią do czynienia chyba w każdej dziedzinie życia społecznego.

Kolejnym wariantem mechanizmu opartego na naśladownictwie i akceptacji jest mechanizm grupy wiodącej ${ }^{51}$. Polega on na naśladowaniu pewnej grupy, jej stylu życia wraz ze wszystkimi jego atrybutami. Zazwyczaj jest to styl życia wzorcowy, do którego jednostka dąży, ucieleśniany przez ludzi uznanych, którzy z racji swojej pozycji, prestiżu, statusu społecznego, posiadanej wiedzy są przedmiotem powszechnego szacunku i akceptacji ze strony całego społeczeństwa. Przykładem są tutaj jakże często pokazywane pewne grupy, obdarzone szacunkiem społecznym, które swoje szczęście i zadowolenie z życia czerpią z innych źródeł niż konsumpcja. Ich zaangażowanie na rzecz innych spraw niż konsumpcja ma być wzorem do naśladowania. $Z$ reguły jest to działalność różnego ro-

nych. Obserwator reakcji emocjonalnych modela może nie tylko doznawać podobnych reakcji, lecz może także zacząć reagować emocjonalnie na bodziec, który wywołał reakcje u modela. Omówienie za: S. C. Hall, G. Lindzey, Teorie osobowości, Warszawa 2002, s. 569-570.

${ }^{50}$ T. Kocowski, Taktyka i strategia kierowania motywacja ludzka $w$ skali masowej, w: A. Podgórecki (red.), Socjotechnika. Style działania, Warszawa 1972, s. 479.

${ }_{51}$ Ibidem, s. 480-481. 
dzaju, jakże modnego obecnie wolontariatu (choć trzeba zauważyć, że często działania takie podejmowane są w celach partykularnych - wpis do $\mathrm{CV}$ ). Nigdy nie przedstawia się tego typu zajęć jako pewnego rodzaju poświęcenia, ale raczej jako przejaw pewnej wyższej potrzeby. Część tych osób jest nawet nieświadoma, że jest wykorzystywana instrumentalnie przez podmiot sterujący w socjotechnice antykonsumpcji.

Działania socjotechniczne, czyli oddziaływania systemów sterujących na systemy sterowane mogą być prowadzone różnymi środkami. Wyróżniamy tu jako typy idealne dwa rodzaje oddziaływań ${ }^{52}$. Pierwszy to oddziaływanie poprzez emocje i uczucia, których cechą wspólną jest wpływanie na te części psychiki ludzkiej, które są słabo bądź wcale nie kontrolowane przez świadomość. Drugi to oddziaływanie poprzez intelekt lub umysł - te części osobowości, o których twierdzi się na ogół, że są dobrze (a w każdym razie lepiej niż poprzednie) kontrolowane przez świadomość. W praktyce każde prawie oddziaływanie socjotechniczne jest po części kierowane na emocje i uczucia, po części na intelekt. Zależnie od tego, który typ oddziaływań przeważa, mówić będziemy dla uproszczenia o emocjonalnym lub intelektualnym oddziaływaniu. Wybór sposobu kształtowania postaw będzie każdorazowo podyktowany okolicznościami i potrzebami systemu sterującego (w zależności, jaki chcemy uzyskać np. dominujący komponent postawy). Analizując post factum dotychczasowe oddziaływania socjotechniczne wobec społeczeństwa (przynajmniej te w XX-wiecznych demokracjach, czasami niefortunnie określanych mianem demokracji masowych), należy stwierdzić, że w przeważającej części były to oddziaływania oparte na emocjach. Zdaniem Brauda to właśnie skuteczne sterowanie emocjonalnymi wyzwaniami życia społecznego przyczyniło się do utrzymania stabilności demokracji w długim okresie czasu. Wydaje się, że uprawnione jest twierdzenie, jakoby upowszechnienie demokracji niejako wymusiło przewagę wpływów emocjonalnych nad racjonalnymi. Jak zauważa J. Ellul: ,nie apeluje się normalnie do intelektu jednostki, albowiem proces przekonywania rozumowego jest zbyt długi i niepewny"53. Proces ten wykorzystuje irracjonalność natury ludzkiej. Na emocjonalny aspekt motywacji działalności ludzkiej w teorii

52 M. K. Mlicki, Socjotechnika. Zagadnienia etyczne i prakseologiczne, Wrocław 1986, s. 23.

53 J. Ellul, Propaganda. The Formation of Men's Attitudes, New York 1965, s. 37 , cyt. za: L. Wojtasik, Zarys psychologii propagandy, Warszawa 1973, s. 64. 
wskazywał V. Pareto ${ }^{54}$. Niebagatelny wpływ na ten fakt miał także rozwój mediów masowych i ich charakter, bez których funkcjonowanie demokracji w społeczeństwie masowym byłoby niemożliwie. Zgodzić się należy, że tak jak dotychczas tak i teraz, ostatecznym celem sterowania ludzkim umysłem jest bierność, która zapewnia utrzymanie status quo. „Bierność stanowi pożywkę sama dla siebie, niszcząc zdolność do jakiejkolwiek społecznej akcji, która mogłaby zmienić warunki uniemożliwiające obecnie spełnienie ludzkich nadziei" ${ }^{55}$. Podsumowując, można wskazać, że system sterujący odwołuje się do uczuć jednostki, ponieważ jest to sposób, po pierwsze - najbardziej uniwersalny (katalog emocji jest podobny u wszystkich ludzi), po drugie - ekonomiczny (m.in. z wyżej wskazanego powodu przekaz może być kierowany do najszerszego kręgu odbiorców) i po trzecie - skuteczny zarówno ze względu na wspominaną irracjonalność natury ludzkiej, jak i fakt, że pozwala wpływać nie tylko na zachowania, lecz także na postawy ludzkie, co jest oczywiście zdecydowanie bardziej trwałe $^{56}$. I tak cała argumentacja ekologów w głównej mierze ma charakter emocjonalny. Bazuje na irracjonalnym strachu społeczeństwa. Jak wskazują liczni badacze, zmiany klimatyczne (według ekologów będące następstwem zwiększonej konsumpcji) wcale nie są takie duże, a już na pewno nie takie jak opisują je ekologowie. Podobnie sprawa wygląda, jeśli idzie o zasoby surowców naturalnych. Tak więc to co na gruncie racjonalnym powinno być odrzucone, na gruncie emocji jest w pełni akceptowane.

54 V. Pareto, Uczucia i działania. Fragmenty socjologiczne, Warszawa 1994. Pareto twierdził, że działania ludzkie są nielogiczne i że kierują nimi irracjonalne uczucia, które przybierają postać derywacji. To uczucia, które są względnie stałe w ciagu wieków, stanowią siłę napędową działań. Uczucia przejawiają się poprzez rezydua, które są energią motywująca do działań. Rezydua decydują nie tylko o postępowaniu, lecz także o formułowanych pojęciach, teoriach, ideologiach, które są werbalnymi reakcjami na rezydua. Jak pisze we wstępie do książki Pareta - Andrzej Kojder: „Ludzie akceptują rozmaite poglądy, programy czy hasła nie dlatego, że są one prawdziwe lub użyteczne, lecz dlatego, że odpowiadają ich rezyduom. Wszystkie słowne sformułowania, wszystkie systemy idei, które nadają działaniom pozory logiczności, Pareto nazwał derywacjami. Są one produktem przyrodzonej człowiekowi skłonności, by wszystkiemu, co ludzie robią w życiu społecznym, nadać jakieś uzasadnienie. W większości wypadków są to uzasadnienia ideologiczne, pseudologiczne, odporne na argumentację, doświadczenie i logiczne rozumowanie, albowiem w naturze ludzkiej leży skłonność do mistyfikacji i konfabulacji”. A. Kojder, Wstęp, w: ibidem, s. XIV/XV.

55 H. I. Schiller, Sternicy świadomości, Kraków 1976, s. 48.

56 P. Pawełczyk, D. Piontek, Socjotechnika w komunikowaniu politycznym, Poznań 1999, s. 32. 


\section{Media w socjotechnice antykonsumpcji}

Tak jak skuteczność socjotechniki konsumpcji związana była z mediami masowymi, tak też trudno sobie wyobrazić socjotechnikę antykonsumpcji bez nich. Rozwój mediów pozwolił na stabilne funkcjonowanie masowego społeczeństwa, poprzez możliwość dyscyplinowania na wielką skalę. Obecnie mówi się o mediach, używając modnego przedrostka post, dzięki którym możliwie jest (lub jest jego wytworem) społeczeństwo postmasowe. Segmentacja mediów (w przyszłości postępująca konwergencja mediów pozwoli jeszcze lepiej trafiać do szerokiego kręgu odbiorców ze spersonalizowanym przekazem) oraz rozwój technik marketingowych pozwala obecnie prowadzić socjotechnikę antykonsumpcji w stosunku do wyznaczonych docelowych grup. Wystarczy tylko spojrzeć na reklamy w bezpłatnych kanałach telewizyjnych skierowanych do większości społeczeństwa, czyli do szerokiego targetu. Odnajdziemy tam głównie reklamy produktów FCMG (Fast Moving Consumer Goods) - czyli produkty szybko rotujące lub szybkozbywalne, artykuły pierwszej potrzeby takie jak proszki do prania, produkty spożywcze, podstawowe leki. Wszystkie one odnoszą się do zaspokojenia elementarnych potrzeb. Reklamy produktów ekskluzywnych zamieszczane są w dobranych do odpowiedniego odbiorcy mediach, które są dostępne dla nielicznych - wiąże się to z opłatami abonamentowymi w telewizjach kablowych lub z wysoką cena czasopism tzw. kolorowych.

Siła mediów od początku tkwiła w olbrzymiej popularności i dostępności. W socjotechnice antykonsumpcji największą rolę odgrywa telewizja, to ona jest głównie źródłem informacji dla konsumentów tzw. ułomnych (w tej grupie poziom czytelnictwa jest dramatycznie niski). W przypadku socjotechniki antykonsumpcji, chodzi o wywieranie normatywnego wpływu na jednostki, który polega na dostarczaniu widzom (publiczności) - ,społecznego dowodu słuszności”, ${ }^{57}$. Zasada społecznego dowodu słuszności głosi czy coś jest poprawne, czy nie, decydujemy poprzez odwołanie się do tego, co myślą na dany temat inni ludzie. R. Cialdini wskazuje, że w szczególności zasada ta obowiązuje przy określaniu jakie postępowanie jest poprawne, a jakie nie. Uważamy jakieś zachowanie za poprawne w danej sytuacji o tyle, o ile widzimy innych, którzy tak właśnie się zachowują.

57 R. Cialdini, Wywieranie wpływu na ludzi. Teoria i praktyka, Gdańsk 1999, s. $112-153$. 
Społeczny dowód słuszności może dostarczać nam wiedzy - jak postępować, a także jak nie postępować. Wszelkie zachowania społecznie akceptowane tworzą pewne scenariusze, którymi mamy kierować się w życiu, natomiast zachowania dysfunkcjonalne wobec systemu społecznego, pokazywane są jako nie akceptowane, a przez to dostarczają wiedzy jak nie należy postępować. Mamy tutaj do czynienia z modelowaniem pozytywnym i negatywnym. W tym drugim aspekcie, ciekawie jawi się pokazywanie w mediach, w dość karykaturalnej formie aktów nadmiernej konsumpcji w zestawieniu z biedą trzeciego świata. Postawa konsumpcyjna zostaje wyśmiana lub napiętnowana (w zależności do jakiej publiczności kierowany jest przekaz).

Społeczny dowód słuszności jest najsilniejszy, kiedy pochodzi od wielu różnych osób. Dlatego też, pokazywane wskazówki, dotyczące jak się zachować, płyną od osób o różnorodnej pozycji społecznej, różnym statusie materialnym, z różnych źródeł. Taki dowód słuszności pochodzący zarazem od gwiazdy telewizyjnej, naukowego autorytetu, prezentowany jako wyniki badań społecznych, zwiększa prawdopodobieństwo kierowania się nim przez jednostki. Najbardziej skłonni jesteśmy uznawać działania innych za dowód słuszności wtedy, gdy jesteśmy niepewni swego, gdy sytuacja jest niejasna i dwuznaczna, gdy króluje niepewność ${ }^{58}$. Cialdini wskazuje na istotne ograniczenie reguły dowodu społecznego: „Wskazówek co do poprawności naszego własnego postępowania szczególnie poszukujemy w zachowaniu ludzi, których widzimy jako podobnych do nas" ${ }^{59}$. Stąd właśnie w mediach coraz więcej tzw. zwykłych ludzi. Coraz częściej wskazuje się, że rola mediów nie tylko ogranicza się do tworzenia wzorów i punktów odniesień dla tożsamości widza, ale także tworzeniem standardów percepcji i oceny innych ludzi ${ }^{60}$.

Reasumując powyższe spostrzeżenia, należy wskazać, że od skuteczności działań związanych z socjotechniką antykonsumpcji, zależy utrzymanie stabilności współczesnego systemu demokratycznego. Zakładając oczywiście, że obecna trajektoria zmian wyznaczająca warunki socjoekonomiczne życia społeczeństw (głównie chodzi tutaj o polaryzację materialnego statusu różnych grup społecznych) będzie utrzymana. Jeśliby obecny trend miał się odwrócić, to działania związane z socjotechniką antykonsumpcji, przynajmniej w takim rozmiarze jak obecnie, nie będa

58 R. Cialdini, op. cit., s. 124-125.

59 Ibidem, s. 134.

60 B. Reeves, C. Nass, Media i ludzie, Warszawa 2000, s. 57. 
konieczne. Wtedy zapewne także, postawa antykonsumpcyjna powróciłaby do swego pierwowzoru. Stałaby się znowu wyrazem sprzeciwu wobec panującego porządku społecznego lub fanaberią grupy elit.

\section{Summary}

The efficiency of activities related to the sociotechnics of anti-consumption is crucial to maintain the stability of a modern democratic system. This is of course, if we assume that the present direction of changes which establish the social and economic factors of life of societies (mainly the polarization of material status of various social groups) will be maintained. If the present tendency was to be reversed the activities related to the sociotechnics of anti-consumption would not be necessary, at least to the extent required at present. Then, the anti-consumption attitude would be likely to return to its original form, and it would again become the expression of protest against the social order, or a whim of elite groups. 
